\title{
KEBIASAAN MAKAN SAYUR DAN BUAH PADA PETANI YANG BERKAITAN DENGAN KEJADIAN KATARAK DI KECAMATAN TELUK JAMBE JAWA BARAT
}

\author{
Laurentia Mihardja; Lusianawaty Tana dan Lannywati Ghani \\ Pusat Penelitian dan Pengembangan Biomedis dan \\ Farmasi, Depkes RI
}

\section{ABSTRACT \\ RISK OF CATARACT ASSOCIATED WITH FRUIT AND VEGETABLE INTAKE AMONG FARMERS OF WEST JAVA}

Risk for cataract increases with age, but also has been associated with exposure to sunlight, and factors such as smoking, and diet. We explored the risk of cataract in West Java, and found a strong association with diet, and a higher risk among malnourished adults. The aim of the study was to know the relationship between risk of cataract and consumption of fruit and vegetables intake among farmers of West Java. This study using cross sectional design which was conducted among farmers and their families in West Teluk Jambe subdistrict, Karawang West Java, Indonesia. Randomly sampled individual 30 years and older in the population and identified 1223 subjecs to participated in the study. Each subject was interviewed about vegetables and fruit consumption per day and per week previously and historical quantity of intake by use of questionnaire and food models. Anthropometry measurement (weight and height) were also undertaken. Ocular examinations were carried out by opthalmologist. The results showed that risk of cataract increases by age. The subjects for $\geq 55$ years vs $30-54$ years old give an odds ratio of 30.6. (95\% Cl: 22.04- 42.5, $\mathrm{p}=0.0001$ ). Consumption of vegetables $<5$ serving vs $\geq 5$ serving perday had a significant odds ratio for cataract risks of 1.74 ( $95 \% \mathrm{Cl}$ : $1.04-$ 2.91, $p=0.031$ ). Intake of colourfull fruits had a similar odds ratio for $<1$ serving vs $\geq 1$ serving per day with an odds ratio for cataracts risks of $1.74(95 \% \mathrm{Cl}: 1.26-2.4, \mathrm{p}=0.001)$. Underweight (body mass index $<18.5$ ) vs with > or = normal body weight was also very important with an odds ratio of 4 ( $95 \%$ Cl: $3.2-5.8, p=0.0001$ ). Using binary logistic regression only ages, and nutritional status showed a significant relationship with cataract risk. This study demonstrates that consumption of vegetables and fruits $\geq 5$ serving per day, intake colourfull fruits $\geq 1$ serving per day and having good nutrition with status BMI normal can reduce the risk for cataracs. To prevent cataracts it is important to promote the consumption of vegetables and fruits, colourful fruit and to promote good nutritional status.

Key words: cataract, fruit, vegetable, underweight

\section{PENDAHULUAN}

K atarak atau kekeruhan pada lensa disebabkan presipitasi protein atau bahan lainnya sehubungan dengan proses degenerasi atau bertambahnya usia. Protein dalam lensa mengalami kerusakan akibat (foto) oksidasi. Bertumpuknya protein yang rusak merupakan bagian dari aktivitas yang meningkat dari proteolisis. Protein yang rusak berakumulasi, beragregasi dan berpresipitasi. Katarak biasanya berkembang secara perlahan sehingga seringkali tidak disadari oleh penderitanya. Jika katarak hanya terjadi pada sisi luar lensa mata, tidak ada perubahan penglihatan yang berarti. Tapi jika katarak terjadi dekat pusat lensa, akan timbul gangguan penglihatan $n^{1,2}$. Alasan mengapa katarak terjadi seiring dengan bertambahnya usia tidak diketahui pasti, tetapi radiasi 
ultraviolet, terutama dari matahari, dianggap berperan terhadap perubahan kimia pada lensa yang selanjutnya menjadi katarak. Pada percobaan dibuktikan bahwa radiasi ultra violet (UV) dapat mengeruhkan lensa dengan membentuk fragmen kimia yang sangat reaktif yang disebut radikal bebas. Selanjutnya radikal bebas ini akan merusak struktur lensa. Katarak berkembang dengan lambat, penglihatan berangsur-angsur terganggu sampai gangguan tersebut menjadi demikian parah².

Radiasi ultraviolet dari matahari berimplikasi pada katarak, tetapi kerusakan itu lebih besar bila terdapat defisiensi vitamin $C$. Vitamin C dan kemungkinan antioksidan lainnya melindungi sel-sel dari kerusakan sinar matahari. Terlalu banyak terjadi oksidasi dan tidak cukupnya proteksi (antioksidan) dapat mengarah kepada terjadinya katarak. Intake vitamin $\mathrm{C}$ dosis tinggi dihubungkan dengan berkurangnya resiko katarak. Anjuran kecukupan gizi untuk vitamin $C$ adalah $90 \mathrm{mg}$, hanya cukup untuk mencegah defisiensi, bukan sebagai terapi. Untuk mendapat kecukupan vitamin $C$ dalam lensa mata, intake harus lebih dari yang dianjurkan. Konsumsi vitamin $\mathrm{C}$ tinggi bertujuan meningkatkan konsentrasi vitamin $\mathrm{C}$ di dalam aqueous medium dari mata, yang melindungi lensa dari kerusakan. Vitamin C banyak terdapat dalam buah-buahan dan sayuran $^{3}$. Antioksidan lain yang dapat membantu yaitu vitamin $\mathrm{E}$, Se, glutathion, dan bermacam-macam bioflavonoids dan karoten yang terdapat di dalam sayur dan buah berwarna yang segar. Pigmen berwarna mengandung antioksidan yang dapat melindungi penglihatan. Makanan yang banyak mengandung pigmen berwarna (karoten) antara lain brokoli, jagung, bayam dan tomat. Salah satu penelitian memperlihatkan bahwa responden yang makan lebih banyak karoten, lutein dan zeaxanthin 18 persen lebih rendah tejadi katarak ${ }^{4}$. Penelitian Brown NA dkk memperlihatkan seng dan beta-karoten dapat berfungsi mencegah degenerasi macula ${ }^{5}$. Penelitian menunjukkan suplemen dengan "bioflavonoid blueberry" dan vitamin E menghambat pembentukan katarak pada 49 dari 50 pasien ${ }^{4}$. Mempertahankan level selenium penting untuk mencegah katarak . Faktor risiko katarak dengan tipe nuklear termasuk gizi kurang, selenium (Se) dan vitamin $\mathrm{E}$ rendah dalam lensa. Se yang rendah menyebabkan 2,5 kali peningkatan radikal bebas yang menginduksi hidrogen peroksida $(\mathrm{HO})$ di lensa. HO dinetralisir oleh seleniumdependent antioksidan glutathione peroxidase ${ }^{6}$. Robertson melaporkan pasien dengan katarak cenderung mempunyai tingkat vitamin $\mathrm{C}, \mathrm{E}$ atau karotenoid serum lebih rendah dibandingkan kontrol $^{7}$. Kurniaz melaporkan dari hasil penelitian, bahwa penggunaan suplemen tiamin, riboflavin, niasin, vitamin $\mathrm{A}$, asam folat, vitamin B12 dapat menurunkan terjadinya katarak $^{8}$. Penelitian Sirlan di Indonesia menunjukkan bahwa kekurangan riboflavin berpengaruh terhadap penurunan aktivitas glutation reduktase darah, yang mempunyai hubungan dengan kejadian katarak pada usia produktif. Disimpulkan bahwa kekurangan riboflavin mempengaruhi kejadian katarak pada usia produktif tidak secara langsung, akan tetapi peningkatan konsumsi riboflavin diharapkan dapat meningkatkan aktivitas glutation reduktase darah, dan peningkatan aktivitas enzim tersebut dapat menunda kejadian katarak pada usia produktif?. Penelitian kohort yang dilakukan oleh Christen W.G dkk. menghasilkan bahwa dari 39876 wanita dengan diet tinggi sayur dan buah dapat mengurangi terjadinya risiko katarak $10-15$ persen dibandingkan kelompok dengan konsumsi sayur dan buah yang rendah ${ }^{10}$.

Katarak dapat dicegah, ditunda, diperlambat dan mungkin sembuh pada tahap awal dengan memperbaiki secara tuntas penyebab penyakit ${ }^{3}$. Dengan makan sayur dan buah yang optimal diharapkan dapat mencegah katarak seperti yang didapat pada penelitian sebelumnya. Apakah seluruh sayur dan buah mempunyai efek yang sama terhadap pencegahan katarak? Sayur dan 
buah berwarna mempunyai kandungan karoten lebih tinggi dibandingkan yang tidak berwarna $^{10}$. Tujuan penelitian ini untuk menilai kebiasaan konsumsi sayur dan buah dari petani dan keluarganya dikaitkan dengan kejadian katarak.

\section{METODE}

Penelitian dengan desain potong lintang (cross-sectional) dilakukan pada populasi petani di daerah kecamatan Teluk Jambe Barat, Kabupaten Karawang, provinsi Jawa Barat. Dipilih daerah kecamatan Teluk Jambe Barat karena merupakan daerah dengan penduduk mayoritas petani, perpindahan penduduk kecil, rujukan kasus katarak paling tinggi dibandingkan kecamatan lainnya dan terdapat Balai Kesehatan Mata Masyarakat (BKMM) dengan dokter spesialis mata sebagai tempat rujukan kasus katarak.

\section{Sampel}

Populasi adalah petani dan keluarganya di kecamatan Teluk Jambe Barat Kabupaten Karawang. Sampel di pilih secara acak sederhana dengan kriteria inklusi yaitu umur minimal 30 tahun, berdomisili dan beraktivitas di daerah Karawang, bersedia mengikuti penelitian dengan menandatangani informed consent. Adapun kriteria eksklusi adalah sedang menderita penyakit berat, demensia, buta karena cacat, tidak mempunyai kedua bola mata dan pernah operasi katarak/lensa mata pada kedua mata.

\section{Pengumpulan data}

Pengumpulan data dilakukan dengan wawancara, pengukuran dan pemeriksaan. Wawancara yang berkaitan dengan konsumsi sayur dan buah dilakukan dengan menggunakan kuesioner dan alat bantu food model. Ditanyakan kebiasaan makan sayur dan buah per hari dan 1 minggu terakhir serta jumlah yang dimakan. Food model digunakan untuk mengetahui macam dan besar porsi sayur dan buah yang dikonsumsi perkali makan. Visus diukur dengan menggunakan Snellen chard dan pinhole. Pemeriksaan katarak dilakukan oleh dokter spesialis mata dengan ophthalmoscope tanpa midriatika. Pengukuran berat badan menggunakan timbangan SECA dengan ketelitian 0,1 kg. Pengukuran tinggi badan menggunakan mikrotoise dengan ketelitian 0,1 cm. Analisis data menggunakan program SPSS 15 dengan uji statistik chi square dan analisis logistik regresi ganda.

\section{Persetujuan Etik}

Persetujuan etik penelitian didapat dari Komisi Etik Badan Penelitian dan Pengembangan Kesehatan.

\section{HASIL}

\section{Kelompok Umur Penderita Katarak}

Responden yang memenuhi kriteria inklusi dan eksklusi sebanyak 1223 orang (90,54\%). Usia terendah 30 tahun, tertinggi 96 tahun dengan rata-rata umur 48,9 (SD 12,3). Secara keseluruhan kasus katarak yang ditemukan pada penelitian ini mencapai 37,9 persen. Kelompok umur $\geq 55$ tahun menduduki persentase menderita katarak paling tinggi yaitu 84,1 persen dengan perincian usia 55-64 tahun sebesar 76,9 persen dan 65 tahun keatas sebesar 95,6 persen. Penderita katarak paling rendah ditemukan pada kelompok umur 30-44 tahun ( Tabel 1). 
Tabel 1

Sebaran Karakteristik Responden Berdasarkan Umur dan Hasil Pemeriksaan Mata Oleh Dokter Spesialis Mata

\begin{tabular}{cccc}
\hline Kelompok Umur (tahun) & Jumlah $(\mathbf{n})$ & $\begin{array}{c}\text { Katarak } \\
(\mathbf{\%})\end{array}$ & $\begin{array}{c}\text { Tidak Katarak } \\
(\%)\end{array}$ \\
\hline $30-44$ & 494 & 4,7 & 95,3 \\
$45-54$ & 320 & 30,3 & 69,7 \\
$55+$ & 409 & 84,1 & 15,9 \\
Total & 1223 & 37,9 & 62,1 \\
\hline
\end{tabular}

Dengan analisis bivariat menunjukkan bahwa kelompok responden dengan umur $\geq 55$ tahun jauh lebih banyak menderita katarak dan berisiko 30,6 kali lebih tinggi dibandingkan responden dengan umur $<55$ tahun $(P=0,0001)$.

\section{Kebiasaan Makan Sayur-Buah}

Pada umumnya responden setiap hari mengonsumsi sayur - buah $(97,2 \%)$. Hanya 2,8 persen yang tidak sama sekali makan sayur dan buah setiap hari selama 1 minggu terakhir (Tabel 2)

Tabel 2

Sebaran Karakteristik Responden Berdasarkan Kebiasaan Makan Sayur Dan Buah Perhari Berdasarkan Kelompok Umur

\begin{tabular}{lccccccc}
\hline \multirow{3}{*}{ Kelompok Umur } & \multicolumn{6}{c}{ Persentase Responden Yang Makan Sayur Buah Satu Hari (\%) } \\
\cline { 2 - 8 } & 0 porsi & $\begin{array}{c}>-<1 \\
\text { porsi }\end{array}$ & $\begin{array}{c}1-<2 \\
\text { porsi }\end{array}$ & $\begin{array}{c}2-<3 \\
\text { porsi }\end{array}$ & $\begin{array}{c}3-<4 \\
\text { porsi }\end{array}$ & $\begin{array}{c}4-<5 \\
\text { porsi }\end{array}$ & $\geq 5$ porsi \\
\cline { 2 - 8 } -44 tahun & 2,1 & 22,5 & 32.8 & 20,0 & 10,1 & 4,0 & 8,5 \\
45 -54 tahun & 3,1 & 30,6 & 31.6 & 15,3 & 6,3 & 5,0 & 8,1 \\
$\geq 55$ tahun & 3,4 & 35,0 & 27.9 & 17,4 & 7,8 & 5,9 & 2,7 \\
\hline Total (1223 orang) & $\mathbf{2 , 8}$ & $\mathbf{2 8 . 8}$ & $\mathbf{3 0 . 8}$ & $\mathbf{1 7 , 9}$ & $\mathbf{8 , 3}$ & $\mathbf{4 , 9}$ & $\mathbf{6 , 5}$ \\
\hline
\end{tabular}

Respoden yang mengonsumsi sayurbuah $\geq 5$ porsi/hari sesuai anjuran WHO hanya 6,5 persen. Kelompok usia 55 tahun keatas yang makan sayur buah $\geq 5$ porsi/hari menunjukkan persentase paling rendah yaitu 2,7 persen. Kelompok usia $30-44$ tahun hampir sama dengan kelompok $45-54$ tahun yaitu 8,5 persen dan 8,1 persen. Responden rata-rata mengonsumsi sayur dan buah 1,9 porsi /hari dengan rincian sayur 1,0 porsi /hari dan buah 0,9 porsi/hari. Responden yang makan sayur- buah $<5$ porsi/hari persentase yang menderita katarak jauh lebih banyak $(p=0,031)$ yaitu 38,7 persen dibandingkan dengan responden yang makan sayur buah $\geq 5$ porsi/hari $(26,6 \%)$ dan risiko kejadian katarak 1,74 kali lebih tinggi (95\%Cl:1,04 - 2,91 $\mathrm{p}=0.03)$. Responden yang mempunyai kebiasaan makan sayuran berwarna minimal 1 porsi/ hari 32,6 persen, dan yang mempunyai kebiasaan makan buah berwarna minimal 1 porsi/hari hanya 17,9 persen. Pada penelitian ini yang dimaksud 
dengan buah berwarna adalah : alpukat, jeruk, mangga, papaya dan buah putih seperti pisang, duku, sirsak, rambutan. Buah yang dimakan adalah buah segar (bukan buah kaleng atau dimasak). Sayuran berwarna yang dimakan responden adalah bayam, kangkung, sawi hijau, wortel, dan sayur putih seperti kol, lobak, labu siam, ketimun, sawi putih (tabel 3).
Yang dimaksud dengan besaran $\geq 1$ porsi adalah setiap hari selalu ada 1 porsi atau lebih yang dikonsumsi. Satu porsi sayur = 1 satuan penukar (misalnya 100 gram bayam mentah ). Adapun yang dimaksud dengan 1 porsi buah = 1 satuan penukar, misalnya pisang 1 porsi $=50$ gram.

Tabel 3

Sebaran Karakteristik Responden Berdasarkan Kebiasaan Makan Sayur Dan Buah Berdasar Warna Rata-Rata 1 Porsi Perhari

\begin{tabular}{ccc}
\hline \multicolumn{1}{c}{ Variabel } & Jumlah & Persen \\
\hline Sayuran berwarna (porsi/hari) & 824 & \\
$<1$ & 399 & 67,4 \\
$\geq 1$ & & 32,6 \\
Sayuran putih (porsi/hari) & 1131 & 92,5 \\
$<1$ & 92 & 7,5 \\
$\geq 1$ & 1004 & 82,1 \\
Buah-buahan berwarna (porsi/hari) & 219 & 17,9 \\
$<1$ & & \\
$\geq 1$ & 999 & 81,7 \\
Buah-buahan putih (porsi/minggu) & 224 & 18,3 \\
$<1$ & & \\
\hline 1 &
\end{tabular}

Tabel 4

Hubungan Antara Kebiasaan Makan Sayur dan Buah Putih atau Berwarna 1 Porsi atau Lebih Perhari dengan Katarak

\begin{tabular}{|c|c|c|c|c|c|c|}
\hline \multirow{2}{*}{$\begin{array}{l}\text { Determinan } \\
\text { (porsi perhari) }\end{array}$} & \multicolumn{2}{|c|}{ Katarak } & \multirow[t]{2}{*}{ OR } & \multicolumn{2}{|c|}{$95 \% \mathrm{Cl}$} & \multirow[t]{2}{*}{$\mathrm{p}$} \\
\hline & $\mathrm{Ya}(\%)$ & Tidak (\%) & & Low & Up & \\
\hline Sayuran berwarna & & & & & & \\
\hline $\begin{array}{l}<1 \text { (824 orang) } \\
\geq 1 \text { (399 orang) }\end{array}$ & $\begin{array}{l}38,7 \\
36,3\end{array}$ & $\begin{array}{l}61,3 \\
63,7\end{array}$ & 1,11 & 0,86 & 1,42 & 0,42 \\
\hline Sayuran putih & & & & & & \\
\hline $\begin{array}{l}<1 \text { (1131 orang) } \\
\geq 1 \text { (92 orang) }\end{array}$ & $\begin{array}{l}38,4 \\
32,6\end{array}$ & $\begin{array}{l}61,6 \\
67,4\end{array}$ & 1,29 & 0,82 & 2,02 & 0,27 \\
\hline Buah berwarna & & & & & & \\
\hline $\begin{array}{l}<1 \text { (1004 orang) } \\
\geq 1 \text { (219 orang) }\end{array}$ & $\begin{array}{l}40,1 \\
17,9\end{array}$ & $\begin{array}{r}59,9 \\
872,1\end{array}$ & 1,74 & 1,26 & 2,4 & $\underline{0,001}$ \\
\hline
\end{tabular}




\begin{tabular}{rrrrrrr}
\hline Buah putih & & & & & & \\
$<1$ (999 orang) & 37,7 & 62,3 & 0,95 & 0,71 & 1,28 & 0,76 \\
$\geq 1$ (224 orang) & 38,8 & 61,2 & &
\end{tabular}

Pada Tabel 4 terlihat bahwa persentase responden dengan kebiasaan makan buah berwarna < 1 porsi /hari lebih banyak yang menderita katarak $(p=0,001)$ yaitu $(40,1 \%)$ dibanding responden yang makan buah berwarna $\geq 1$ porsi/hari $(27,9 \%)$ dan risiko kejadian katarak 1,74 kali lebih tinggi. Responden yang makan sayur berwarna , sayur putih, buah putih <1 porsi/ hari menderita katarak tidak berbeda bermakna dengan responden yang makan $\geq 1$ porsi/ hari

\section{Status Gizi dan Kejadian Katarak}

Hasil penelitian menunjukkan bahwa kejadian katarak lebih banyak ditemukan pada responden dengan status gizi kurang (IMT < 18,5) dibandingkan dengan status gizi normal (IMT $\geq 18,5$ ). Terdapat perbedaan bermakna $(p=0,000)$ terhadap kejadian katarak antara responden berstatus gizi kurang dibandingkan dengan responden berstatus normal. Responden dengan status gizi kurang mempunyai kemungkinan menderita katarak 4,3 kali dibanding responden dengan status gizi normal.

Tabel 5

Hubungan antara Status Gizi dengan Katarak.

\begin{tabular}{|c|c|c|c|c|c|c|}
\hline \multirow{2}{*}{$\begin{array}{l}\text { Determinan } \\
\text { IMT kg/m2 ( } \mathrm{N} \text { orang) }\end{array}$} & \multicolumn{2}{|c|}{ Katarak } & \multirow{2}{*}{ OR } & \multicolumn{2}{|c|}{$95 \% \mathrm{Cl}$} & \multirow[b]{2}{*}{ p } \\
\hline & YA (\%) & TIDAK(\%) & & LOW & UP & \\
\hline$<18,5$ (232 orang) & 66,4 & 33,6 & 12 & 20 & 50 & 0 \\
\hline$\geq 18,5$ (991 orang) & 31,3 & 68,7 & 4.0 & 0.2 & 0.0 & 0,000 \\
\hline
\end{tabular}

Tabel 6

Hubungan antara Umur, Makan Lima Porsi Sayur-Buah, Buah Berwarna dan Status Gizi dengan Kejadian Katarak ( $N=1223)$

\begin{tabular}{|c|c|c|c|c|c|c|}
\hline Determinan & B & SE & Wald & df & $p$ & Exp \\
\hline $\begin{array}{l}\text { Umur (tahun) } \\
\geq 555 \\
30-54\end{array}$ & 3.360 & .229 & 214.471 & 1 & 0.000 & 28.79 \\
\hline Sayur buah & & & & & & \\
\hline $\begin{array}{l}\quad<5 \text { p/hari } \\
\geq 5 \text { p/hari } \\
\text { Buah berwarna }\end{array}$ & -0.006 & .335 & 0.000 & 1 & 0.985 & 0.994 \\
\hline $\begin{array}{l}<1 \text { p/hari } \\
\geq 1 \text { p/hari }\end{array}$ & 0.213 & .216 & 0.975 & 1 & 0.324 & 1.238 \\
\hline
\end{tabular}




\begin{tabular}{rllllll}
\hline $\begin{array}{r}\text { Indeks massa tubuh } \\
<18,5 \mathrm{~kg} / \mathrm{m} 2\end{array}$ & 1.254 & .191 & 43.286 & 1 & 0.000 & 3.503 \\
$\geq 18,5 \mathrm{~kg} / \mathrm{m} 2$ & & & & & & \\
\hline
\end{tabular}

p/hari $=$ porsi perhari 


\section{Determinan yang Berperan dengan Kejadian Katarak}

Dari hasil analisis logistik regresi ganda diperoleh variabel yang paling berperan / berhubungan secara bermakna dengan peningkatan terjadinya katarak adalah usia tua 55 tahun keatas dibandingkan umur 30 54 tahun $(P=0,000)$ dan satus gizi kurang dibandingkan dengan status gizi normal $(p$ $=0,000$ )

\section{BAHASAN}

Pada penelitian didapat prevalensi katarak usia $\geq 30$ tahun pada salah satu atau kedua mata sebesar 37,9 persen. SKRTSURKESNAS 2001 usia $\geq 15$ tahun mendapatkan sebesar 5,2 persen, usia 35 44 tahun 1,2 persen, $45-54$ tahun sebesar 7,3 persen dan $\geq 55$ tahun 73,1 persen $^{12}$. Hasil yang didapat pada penelitian ini lebih tinggi yaitu $30-44$ tahun 4,7 persen, $45-54$ tahun 30,3 persen dan $\geq 55$ tahun 84,1 persen. Hal ini dapat dijelaskan karena pada penelitian ini responden adalah petani yang kerjanya lebih banyak terpapar sinar matahari. Nirmalan dkk mendapatkan prevalensi katarak terjadi usia 40 tahun keatas, di Selatan India sebesar 47,5 persen dan meningkat seiring meningkatnya usia ${ }^{13}$. Hasil penelitian lain mendapatkan prevalensi katarak di Amerika Serikat usia 15 tahun keatas 5,8 persen $^{11}$. Berdasarkan Survei Kesehatan Indera Penglihatan dan Pendengaran tahun 1993-1996 prevalensi katarak pada beberapa propinsi yang dapat mewakili Indonesia sebesar 7,3 persen. Prevalensi katarak pada kelompok usia 5564 tahun sebesar 33,4 persen, dan pada usia lebih 65 tahun 62,2 persen. Prevalensi katarak di daerah pedesaan 6,29 persen, lebih tinggi dibandingkan daerah perkotaan 4,5 persen $^{14}$. Besarnya jumlah penderita katarak di Indonesia diperkirakan berbanding lurus dengan jumlah penduduk usia lanjut. Jumlah penderita akan meningkat seiring dengan terjadinya peningkatan usia lanjut ${ }^{15}$.

WHO menganjurkan makan sayur dan buah minimal 400 gram/hari ( $\geq 5$ porsi sayur dan buah) untuk mencegah penyakit kronis /degeneratif ${ }^{16}$, hanya 6,5 persen responden yang makan sayur buah $\geq 5$ porsi/ hari. Kejadian katarak pada responden dengan kebiasaan makan sayur buah $<5$ porsi/hari lebih tinggi, dengan risiko 1,74 kali dibandingkan dengan responden yang mempunyai kebiasaan makan sayur buah $\geq$ 5 porsi/ hari. Hasil penelitian yang didapat tidak berbeda dengan penelitian Christen W.G dkk. yang menunjukkan diet tinggi sayur dan buah yaitu 6 porsi sayur buah yang terdiri dari 2 porsi buah dan 4 porsi sayur mengurangi terjadinya risiko katarak 10 - 15 persen dibandingkan kelompok dengan intake sayur dan buah lebih rendah ${ }^{10}$.

Kejadian katarak pada responden dengan kebiasaan makan buah berwarna < 1 porsi/hari lebih tinggi yaitu 1,74 kali dibandingkan dengan responden yang makan buah berwarna minimal 1 porsi/hari. Pigmen karoten ( $\mathrm{C} 40 \mathrm{H} 56 \mathrm{O} 2$ ) yang didapat dari alam, terutama dari sayur dan buah berwarna hijau dan kuning mengandung lutein dan zeaxanthin yang merupakan pigmen kuning yang terdapat di macula, yang melindungi sel-sel retina dari kerusakan oksidasi ${ }^{10}$. Hasil penelitian ini juga sesuai dengan hasil penelitian Jacques dan kawan-kawan yang melaporkan bahwa pasien dengan katarak cenderung mempunyai kadar karotenoid dan vitamin $\mathrm{C}$ serum lebih rendah dibandingkan kelompok yang tidak katarak ${ }^{17}$. Data terbaru menunjukkan konsumsi antioksidan seperti vitamin C, karotin dan vitamin $\mathbf{E}$ dihubungkan dengan penundaan berbagai bentuk katarak. Intake sayur dan buah dapat mempertahankan status antioksidan di dalam plasma. Nutrisi yang optimal akan menunda perkembangan katarak $^{10}$.

Persentase katarak pada responden dengan kebiasaan makan sayuran berwarna >1 porsi/ hari lebih sedikit dibandingkan dengan responden yang makan sayuran berwarna $<1$ porsi/ hari, namun perbedaan tersebut tidak bermakna. Riboflavin dan vitamin C tidak dicadangkan dalam tubuh. Asupan vitamin $\mathrm{C}$ yang cukup menunjukkan konsentrasi vitamin $\mathrm{C}$ dalam cairan bola mata dan di dalam lensa meningkat dan 
dapat mengurangi stres oksidatif sehingga dapat mencegah pembentukan katarak². Namun vitamin dan mineral dapat rusak jika memasak sayuran terlalu lama dan temperatur tinggi ${ }^{18}$. Hal ini berbeda dengan buah-buahan yang dikonsumsi dalam bentuk segar tanpa dimasak.

Kelompok yang makan buah putih $<1$ porsi tidak menunjukkan perbedaan berwarna dengan yang makan $\geq 1$ porsi/hari. Buah-buahan berwarna putih mengandung vitamin B1 dan vitamin C. Namun per 100 gram buah-buahan berwarna putih mengandung vitamin lebih sedikit dibandingkan buah-buahan berwarna, sehingga tambahan asupan vitamin dan mineral dari buah berwarna putih tidak banyak $^{19}$.

Pada penelitian ini terlihat walaupun presentase kejadian katarak lebih rendah pada responden dengan kebiasaan makan sayuran berwarna putih $\geq 1$ porsi/hari dibandingkan dengan responden yang makan sayuran putih < 1 porsi/ hari, namun perbedaan tersebut tidak bermakna. Kandungan vitamin $A$, vitamin $B 1$ dan vitamin C sayur berwarna putih tidak sebanyak sayuran bewarna hijau ${ }^{19}$. Faktor cara memasak juga berpengaruh terhadap kandungan vitamin dan mineral ${ }^{18}$.

Responden dengan status gizi kurang menderita katarak lebih tinggi, hal ini dikaitkan karena responden dengan status gizi kurang juga mempunyai kadar vitamin mineral kurang di dalam tubuh. Delcourt dkk mendapatkan undernutrisi dikaitkan dengan rendahnya kadar protein/ asam amino dan defisiensi vitamin seperti niacin, thiamin dan riboflavin yang perlu untuk mempertahankan kesehatan lensa mata ${ }^{20}$. Caulfield dkk mendapatkan kejadian katarak nuclear lebih besar 1,2 kali pada BMI 17 dan 1,13 kali pada BMI 22,5 dibanding BMI $28^{21}$ Foster dkk mendapatkan BMl kuintil terendah menderita katarak cortical 1,8 kali $(95 \% \mathrm{Cl}$ 1,1 -2,9) lebih tinggi dibanding BMI kuintil tertinggi ${ }^{22}$. Kuang dkk mendapatkan BMI < 21 sebagai factor risiko independen terhadap katarak nuklear dan kortikal. Seseorang dengan $\mathrm{BMI} \geq 21$ risiko katarak nuclear menurun tetapi efek protektif ini hanya sampai BMI $28^{23}$.

Pada penelitian ini bila ditinjau dari hasil analisis logistik regressi ganda dari sejumlah variabel yang mempunyai hubungan bermakna dalam meningkatkan terjadinya katarak ternyata faktor yang paling berperan adalah makin tuanya usia dan status gizi yang kurang. Hal ini sesuai dengan penelitian yang didapat Nirmalan ${ }^{13}$, Delcourt $^{20}$, Caufield ${ }^{21}$, Foster ${ }^{22}$ dan Kuang ${ }^{23}$.

\section{KESIMPULAN DAN SARAN}

Katarak meningkat sesuai dengan bertambahnya usia. Makan sayur-buah $\geq 5$ porsi perhari, buah berwarna $\geq 1$ porsi/hari serta status gizi normal memperlihatkan kejadian katarak lebih rendah. Perlu kiranya diberikan penyuluhan kepada masyarakat tentang pentingnya kebiasaan makan sayur buah $\geq 5$ porsi/ hari, buah berwarna $\geq 1$ porsi/ hari serta makan yang cukup untuk mencegah atau memperlambat terjadinya katarak.

\section{RUJUKAN}

1. World Health Organization. Management of Cataract in Primary Health Care Services. $2^{\text {nd }}$ edition. Geneva; 1996.

2. Taylor A. Cataract, Relationships between Nutrition and Oxidation. Journal of the American College of Nutrition. 1993; 12(2):138-46.

3. Varma S.D, et al. Prevention of cataracts by nutritional and metabolic antioksidans. Crit Rev Food Sci and Nutr. 1995; 35:111-29.

4. Issue of Nutrition Science News, By Patrick Quillin, Ph.D., R.D., C.N.S. Colorful fruits and vegetables provide necessary nutrients to see late into life Available at http://www.newhope.com,. Access 18 feb 2008.

5. Brown N.A, et al. Nutrition supplements and the eye. Eye 1998;12:127-33. 
6. Karakucuk $S$, et al. Selenium concentrations in serum, lens, and aqueous humor of patients with senile cataract. Arch Opthalmol Scand 1995; 73: 329-32.

7. Robertson JM, Donner AP. A Possible Role for Vitamin $C$ and $E$ in Cataract Prevention. Am J Clin Nutr. 1991; Jan; 53: $346 \mathrm{~S}$ - 351S.

8. Kurniarz M, Mitchell $P$, Cumming RG, Flood VM. Use Vitamin Supplements and Cataract: The Blue Mountains Eye Study. Am J Ophthalmol 2001 Jul; vol 132 (Issue 1); p.19-26.

9. Sirlan F. Faktor Risiko Buta Katarak Usia Produktif: Tinjauan Khusus Terhadap Enzym Glutation Reduktase dan Riboflavin Darah. Studi Kasus Di Daerah Pantai Sumatera Barat dan Nusa Tenggara Barat. Disertasi. Jakarta, 2000.

10. G Christen, Simin Liu, Debra A Schaumberg and Julie E Buring. Fruit and vegetable intake and the risk of cataract in women. American Journal of Clinical Nutrition 2005; June; Vol. 81, No. 6: 1417-1422.

11. Prevalence and Incidence of Catarcts. Available at http://curresearch.com/adm in/preval.htm. Accesed August 20, 2004.

12. Tim Surkesnas (2002). Laporan SKRT 2001. Studi Morbiditas dan Disabilitas. Jakarta: Badan penelitian dan Pengembangan Kesehatan, Departemen Kesehatan RI, 2002, p. 26.

13. Nirmalan P.K, Robin A.L, Katz J, Tielsch J.M, Thulasiraj R. D, Krishnadas $\mathrm{R}$, and Ramakrishnan $\mathrm{R}$. Risk factors for age related cataract in a rural population of southern India: the Aravind Comprehensive Eye Study. British J Ophthalmol. 2004 August; 88(8): 989-994.

14. SubDit. Bina Kesehatan Mata, Ditjen Binkesmas Depkes RI. Laporan Operasi Katarak Massal dengan Bantuan CBM di 8 Propinsi (Sumatera Utara, Sumatera Barat, Jawa Barat, Sulawesi Utara, Sulawesi Selatan, Kalimantan Timur, Nusa Tenggara Barat dan Nusa Tenggara Timur). Jakarta, 1999.

15. Departemen Kesehatan RI. Rencana Strategis Nasional Penanggulangan Gangguan Penglihatan dan Kebutaan (PGPK) untuk Mencapai Vision 2020. Jakarta, 2003.

16. World Health Report 2002. Reducing risks, promoting healthy lives.

17. Jacques PF, Chylack LT. Epidemiologic Evidence of the Role for the Antioksidan Vitamins and Carotenoids in Cataract Prevention. Am J Clin Nutr 1991; 53(suppl): 352s-355s.

18. Sediaoetama A.D. IImu Gizi. Jakarta: Dian Rakyat, 2004.

19. Direktorat Gizi Departemen Kesehatan RI. Daftar Komposisi Bahan Makanan, Jakarta: Bharatarata, 1999.

20. Delcourt C. cs. Albumin and Transthyretin as Risk Factors for Cataracts. Arch Ophthalmol 2005, 123: $225-232$.

21. Caulfield L.E, West S.K, Barron Y, Ruzafa J.C. Anthropometric status and cataract. American Journal of Clinical Nutrition 1999 Feb, vol 69, no 2: 237 242.

22. Foster PJ, Wong TY, Machin D, Johnson GJ, Seah SK. Risk factors for nuclear, cortical and posterior subcapsular cataracts in the Chinese population of Singapore: the Tanjong Pagar Survey. Br J Ophthalmol 2003, Sep 87(9):1112-20.

23. Kuang TM, Tsai SY, Hsu WM, Cheng CY, Liu JH, Chou P. Body Mass Index and Age Related Cataract. Arch Ophthalmol 2005, vol 123:1109-1114. 